\title{
SÚVISLOSTI KONCEPTU SPOLOČENSKY ZODPOVEDNÉHO PODNIKANIA
}

\author{
Vladimíra Žiačková*
}

Úvod

Spoločensky zodpovedné podnikanie (CSR) je konceptom, ktorý pozitívnym vplyvom na spoločnost' na mikroúrovni ovplyvňuje zároveň celú spoločnost' a úzko súvisí s naliehavou snahou nájst' prostriedky riešenia globálnych problémov dnešného sveta. Tlak na podniky, aby sa začali správat' spoločensky zodpovedne, je odpoved'ou na sociálne a ekonomické výzvy, ktorým čelia komunity všade na svete, a je dôkazom, že ani samotné vlády, ani predstavitelia občianskej spoločnosti nedokážu nájst' dlhodobo udržatel'né riešenia bez zapojenia súkromného sektora.

V súčasnom období zvyšujúcej sa konkurencie, ako aj zvyšujúcich sa požiadaviek zákazníkov, ktoré spôsobujú komplexné zmeny okolia, je samozrejmé, že šancu uspiet' majú len podniky, ktoré sú dostatočne flexibilné. Preto sa počas uplynulých desiatich rokov spoločensky zodpovedné podnikanie stalo rozhodujúcim nástrojom podnikovej politiky.

Podniky nie sú uzatvorené jednotky, ktoré nie sú nezávislé od prostredia, v ktorom pôsobia. Práve naopak - ich aktivity vedú k tomu, že sú závislé od stálej výmeny s vonkajším prostredím a formujú globálny systém, ktorý má ekologickú, ekonomickú a sociálnu stránku. Podniky vytvárajú vzájomný vzt’ah s prostredím, ked’že vplyvy na spoločnost' vyvolané činnost'ou podnikov pôsobia spätne na samotné podniky. Táto súvislost' je známa ako princíp kontextuálnej relativity. Na základe tohto princípu podniky neexistujú izolovane a preto je v ich záujme brat' do úvahy ekologickú, či sociálnu stránku svojich podnikatel'ských aktivít.

\section{CSR vs. trvalo udržatel'ný rozvoj a podnikatel'ská etika}

Trvalo udržatel'ný rozvoj predstavuje koncept, ktorý bol prijatý Svetovou konferenciou OSN pre životné prostredie a rozvoj a neskôr aj Svetovou bankou. Tento koncept vychádza z myšlienky zladit' rast blahobytu žijúcich generácií s ochranou životného prostredia. Klúčovou ideou je nelimitovat' možnosti budúcich generácií. Pojem trvalo udržatel'ný rozvoj (sustainable development) sa prvýkrát objavil v správe Svetovej komisie pre životné prostredie a rozvoj zo summitu v Rio de Janeiru. Spôsob podnikania založený na trvalo udržatel'nom rozvoji hl'adá rovnováhu medzi individuálnymi právami a slobodami a vymedzením zodpovednosti za svoje správanie so zretel’om na dôsledky svojho konania vo vzt’ahu ku všetkým zainteresovaným stranám. [1] Národná stratégia trvalo udržatel'ného rozvoja SR hovorí, že „trvalo udržatelným rozvojom sa rozumie cielený, dlhodobý, komplexný a synergický proces, ovplyvňujúci podmienky a všetky aspekty života, na všetkých

\footnotetext{
* Ing. Vladimíra Žiačková, Žilinská univerzita v Žiline, Fakulta Prevádzky a ekonomiky dopravy a spojov, Katedra spojov, Univerzitná 1, 01026 Žilina, tel. č.: 041/513 3144, e-mail: vladimira.ziackova@fpedas.uniza.sk
} 
úrovniach a smerujúci $k$ takému funkčnému modelu určitého spoločenstva, ktorý kvalitne uspokojuje biologické, materiálne, duchovné a sociálne potreby a záujmy l'udí, pričom eliminuje alebo výrazne obmedzuje zásahy ohrozujúce, poškodzujúce alebo ničiace podmienky a formy života, nezat’ažuje krajinu nad únosnú mieru, rozumne využiva jej zdroje a chráni kultúrne a prírodné dedičstvo. "

Podnikatel'ská etika je normatívna etika, ktorá sa zaoberá pôsobením morálnych noriem a princípov na všetkých úrovniach ekonomiky. Predmetom podnikatel'skej etiky je oblast' konfliktu medzi ekonomickou a etickou racionalitou, medzi individuálnymi a všeobecnými záujmami, medzi princípom maximalizácie zisku a dobrom, resp. princípom spravodlivosti. [2] Vzt'ah medzi podnikaním a spoločenskou zodpovednost'ou je jednou z najaktuálnejších tém podnikatel'skej etiky. [3]

Všetky uvedené teórie vychádzajú zo zodpovednosti voči spoločnosti, sú však viditel'né určité rozdiely. Koncept zodpovedného podnikania je zameraný najmä na externé prostredie a prvotne vychádza z marketingu, trvalo udržatel'ný rozvoj sa zaoberá životným prostredím a podnikatel'ská etika vychádza $z$ princípu etiky samotnej, aplikovanej v podnikatel'skom prostredí. Dodržiavanie princípov zodpovedného podnikania je kl'účom $\mathrm{k}$ trvalo udržatel'nému rozvoju. Ak sa však podnik hlási k princípom podnikatel'skej etiky, tým sa hlási aj k ekologickému a sociálne orientovanému podnikaniu. Jednoznačne môžeme konštatovat', že medzi týmito teóriami je vel’mi tenká línia a často medzi nimi dochádza k názorovým nezrovnalostiam a prelínaniu obsahových vymedzení.

Prelínanie týchto konceptov reflektuje Reidenbachov a Robinov model, v rámci ktorého môžeme určit' niekol'ko vývojových stupňov morálneho rozvoja podnikov, ktoré sú znázornené na obrázku 1.

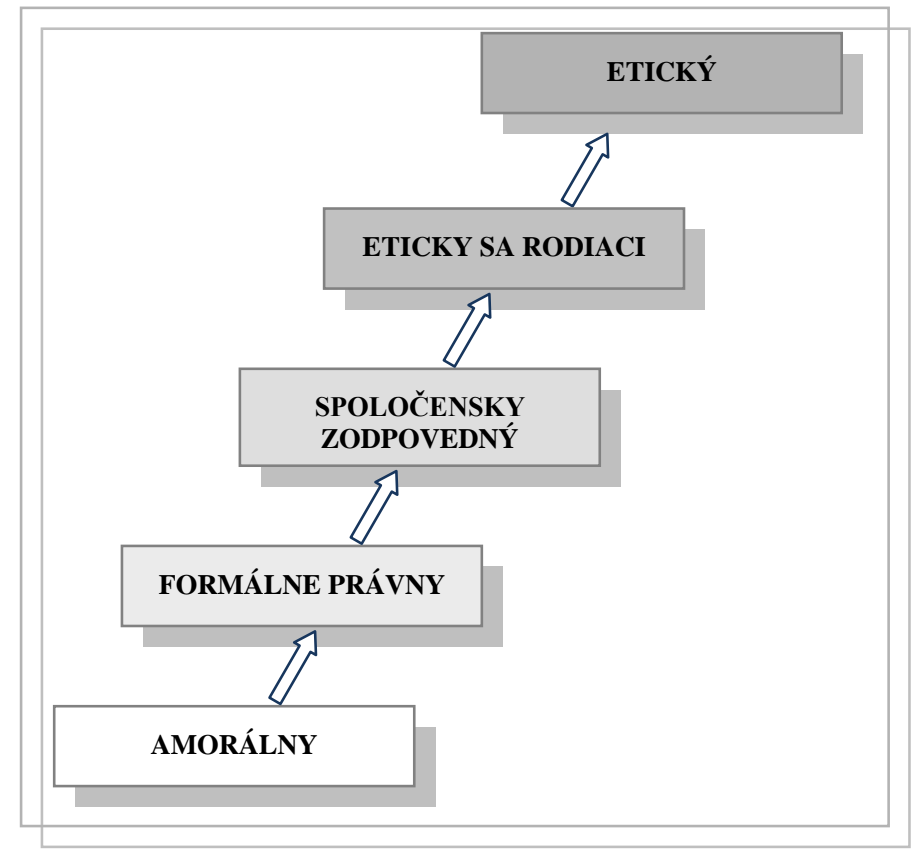

Obrázok 1. Reidenbachov a Robinov model morálneho rozvoja podniku

Zdroj: ROLNÝ, I. - LACINA, L.: Globalizace, etika, ekonomika. 3. vyd. Ostrava: Key Publishing, s.r.o., 2008. 281 s. ISBN 978-80-87071-62-5. s. 65.

Z obrázku vyplýva, že autori rozlišujú z etického hl'adiska celkom 5 vývojových typov podnikov podl'a proporcií ich záujmu o zisk a podnikatel'skú etiku. Adekvátne charakteristikám jednotlivých stupňov môžeme prisúdit' i mieru spoločenskej zodpovednosti podniku. 


\section{1. stupeň - amorálny:}

V tejto fáze sa podnik riadi zásadou, že jeho správanie je etické, pokial' jeho nečisté praktiky nie sú odhalené. Nijaký etický kódex, príp. iná norma tu neexistujú, všetko je podriadené maximalizácii zisku.

\section{2. stupeñ - formálne právny:}

Podnik dbá o to, aby jeho činnost' bola po formálnej právnej stránke v poriadku. Pohybuje sa výhradne na pôde legálnosti, i ked' maximálne využíva legislatívne nedostatky vo svoj prospech. Ak sa objavia spoločenské problémy, na škody, ktoré spôsobí reaguje ex-post. Ak existuje podnikový etický kódex, či iné verejne prezentované zásady, sú zamerané výhradne na požiadavky lojality zamestnancov voči podniku.

\section{3. stupeň - spoločensky zodpovedný:}

Manažment podniku si uvedomuje, že fungovat' len na právnej rovine nestačí, preto vzrastá jeho záujem o podnikatel'skú etiku. Podniková kultúra odráža zodpovedný občiansky postoj, nezameriava sa výhradne na akcionárov, ale berie ohl'ad i na širšiu verejnost'. Zvyšuje sa vyváženost' záujmu o zisk s etickou stránkou spôsobu jeho dosiahnutia. Chýbajú však konkrétne systémové a organizačné opatrenia.

\section{4. stupeň - eticky sa rodiaci:}

Etické hodnoty sa stávajú súčast'ou podnikovej kultúry. Najvyššími hodnotami podnikového manažmentu sa stávajú vytýčené kl'účové hodnoty podniku, ktoré sú deklarované verejnosti. Na tomto stupni sa objavuje aktívna snaha vedenia reagovat' na vznikajúce spoločenské problémy a prihlásit' sa verejne ku spoločenskej zodpovednosti. Pri ekonomických rozhodnutiach manažment prihliada k morálnym hodnotám. I napriek tomu na tomto stupni nie sú spracované etické princípy a zásady do celej organizačnej štruktúry podniku. Etika ešte nie je súčast'ou strategického plánovania, i ked' je na ňu kladený zretel' pri praktickej podnikatel'skej činnosti.

\section{4. stupeň - etický:}

Tento stupeň je charakteristický rovnovážnym záujmom podniku o etické a ekonomické výsledky. Etická analýza ekonomickej činnosti je integrovanou súčastou podnikatel'ských zámerov podniku a jeho strategického plánu a využíva ju na predvídanie možných problémov. Dôraz na etické normy a princípy je súčast'ou všetkých dokumentov a materiálov podniku. V jeho organizačnej štruktúre existujú články vedenia, ktoré sa priamo etickými problémami a ich predchádzaním zaoberajú. [4]

\section{Stakeholderská teória}

„Stakeholderská teória identifikuje najdôležitejšie skupiny, ktoré podnik ovplyvňujú, alebo ktoré ovplyvňuje samotný podnik. Teória pomohla manažérom, ktorí chceli aplikovat' spoločensky zodpovedné podnikanie v praxi, určit', kam majú zacielit' svoju pozornost' a upresnila voči komu majú byt' zodpovední.“ Uvedená teória predstavuje formuláciu stakeholderskej koncepce vytvorenú Fremanom v roku 1984. [4]

Práve od tohto roku sa začínajú objavovat' namiesto všeobecných definícií, ktorých objektom je osoba manažéra, definície reagujúce na stakeholderský prístup. Najlepšie je tento posun viditel'ný v definíciách Johnsona, ktorý tvrdí, že zodpovedný podnik je ten, ktorý berie do úvahy okrem záujmov shareholderov tiež záujmy zamestnancov, dodávatel’ov, lokálnych komunít a spoločnosti. [5]

Táto teória vyjadruje, že podnik vystupuje ako subjekt zodpovednosti za svoje konanie a za dôsledky svojho konania vo vzt’ahu k rozličným skupinám. [1] Pre tieto skupiny sa 
používa pojem stakeholderi, ktorý nemá úplne presný jednoslovný preklad do slovenčiny, kde sa zaužíval preklad „záujmové skupiny“, príp. „zainteresované subjekty“. [6]

S rozvojom stakeholderskej teórie sú odhal'ované d’alšie skupiny, ktoré sú vo vzájomnej interakcii s podnikom a teda voči ktorým by mal byt' podnik zodpovedný. Tým stakeholderská teória, ktorá $\mathrm{v}$ 90. rokoch minulého storočia pomohla spresnit' šírku podnikového záberu voči stakeholderom, začína vd'aka svojmu neustálemu rozvoju strácat' hranice, čo spôsobuje, že sa stáva pre zodpovedné podnikanie nepoužitel'nou, resp. použitel'nou len pri určitom obmedzení a za cenu určitého skreslenia. [4] Aj napriek tomu má stakeholderská teória stále nezanedbatel'ný význam. Možným pozitívnym výsledkom dialógu so zainteresovanými skupinami je napr. šírenie dobrých praktík, vzájomná inšpirácia a motivácia. Vel'mi zretel'ne sa tento aspekt prejavuje $\mathrm{v}$ dodávatel'sko-odberatel'ských vzt'ahoch, napr. ak je odberatel'om podnik s vysokým profilom spoločenskej zodpovednosti a ak bude rovnaké štandardy vyžadovat' od svojich dodávatel'ov.

Dialóg so zainteresovanými subjektmi je zložitý, a to predovšetkým s tými, ktoré podniky nie vždy považujú za svoje zainteresované subjekty (napr. nevládne ekologické organizácie). Má byt' vedený včas, transparentne, efektívne, racionálne a s obojstrannou dobrou vôl'ou. Takto vedený dialóg, môže prinajmenšom pomôct' prekonávat' vzájomnú nedôveru a zaist'ovat' vzájomné pochopenie. Dialóg potom v ideálnych prípadoch môže vyústit' až v dlhodobé partnerstvo medzi jednotlivými sektormi spoločnosti - súkromným a verejným (tzv. cross-sector partnership). [7]

Šírku záberu stakeholderskej koncepcie najvýstižnejšie zobrazuje prehl'ad uvedený v Prílohe A. Podnik potrebuje vediet', ktorí stakeholderi sú najdôležitejší. Preto by mal pred zahájením spoločensky zodpovedných aktivít vytvorit' tzv. analýzu zúčastnených strán. [8] Pomocou analýzy podnik určí klúčových stakeholderov, ktorí majú najväčší vplyv na jeho prosperitu a najvyššie očakávania od jeho zodpovedného podnikania. Pri analýze je možné použit' maticu zobrazenú na obrázku 2.

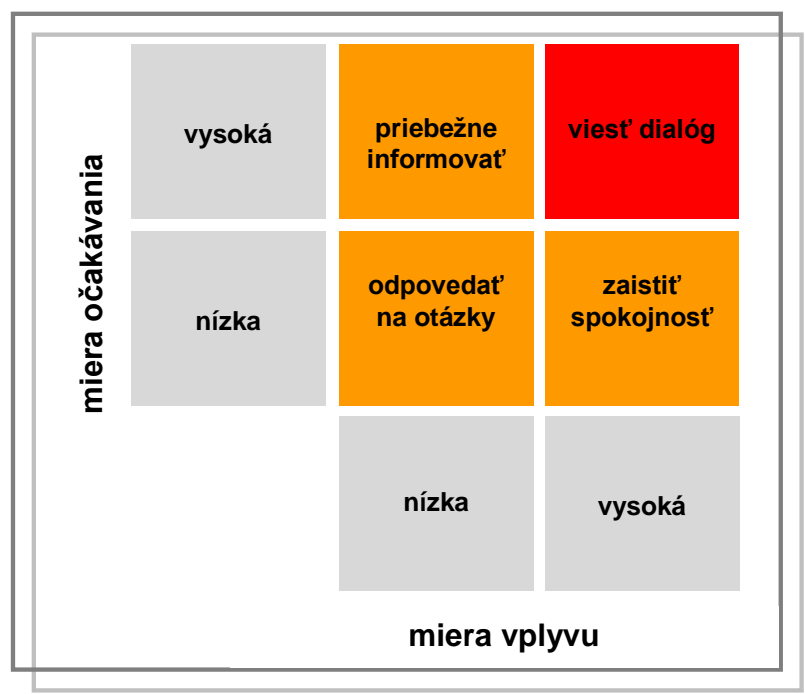

Obrázok 2. Matica analýzy stakeholderov

Zdroj: STEINEROVÁ, M., VÁCLAVÍKOVÁ, A., MERVART, R. (Business Leaders Forum): Společenská odpovědnost firem. Praha: TOP Partners, s.r.o., 2008, s. 17.

Jednotlivým kvadrantom matice podnik priradí stakeholderov podl'a miery ich vplyvu a očakávaní. Tým zároveň získa predstavu o d’alšom postupe voči jednotlivým skupinám. Riadenie spolupráce so stakeholdermi vedie $\mathrm{k}$ ich poznaniu, porozumeniu ich záujmov a k následnému dialógu, ktorého výsledkom je obojstranná spokojnost' - tzv. win - win situácia. Ideálnym stavom je rovnováha medzi aktivitami, ktoré uprednostňuje vedenie podniku a tými, o ktoré prejavia záujem stakeholderi. [9] 


\section{Pyramída spoločensky zodpovedného podnikania}

Archie B. Carroll bol prvým teoretikom, ktorý rozlíšil viac druhov podnikovej zodpovednosti. Pyramída CSR, zobrazená na obrázku 3, by mala manažérom pomôct' systematicky uvažovat' o očakávaniach rozličných skupín stakeholderov. Vymedzenie dimenzií v pyramíde je pragmatické, pretože akceptuje tiež požiadavky na ziskovost' a legálnost' činnosti podnikov. Nerieši však situácie, ked' sa dostanú niektoré zodpovednosti do konfliktu. [5]

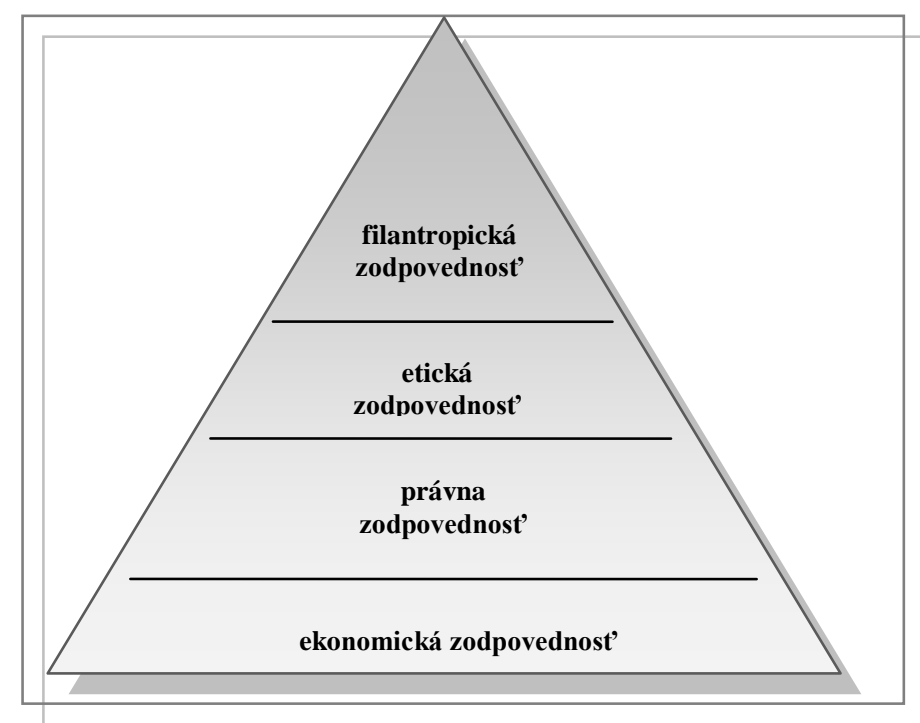

Obrázok 3. Pyramída spoločenskej zodpovednosti

Zdroj: WERTHER, W., CHANDLER, D.: Strategic Corporate Social. Sage Publications, Inc., California, 2006. ISBN 978-1-4129-1373- 7, p. 9.

Podrobnejšia konštrukcia pyramídy spoločenskej zodpovednosti je zameraná na rozlíšenie podnikovej filantropie a zodpovedného podnikania. Toto rozlíšenie reflektuje obrázok 4.

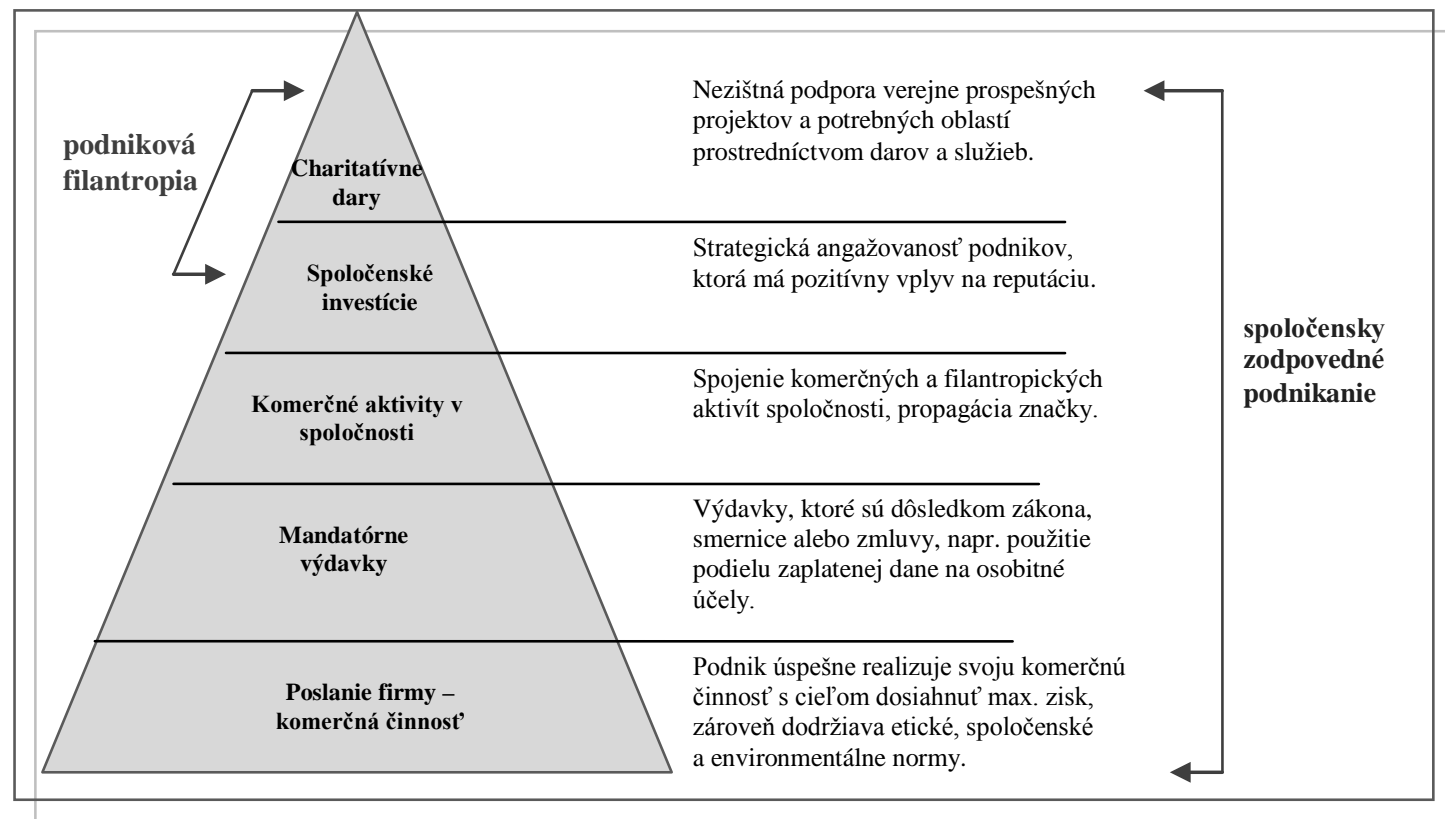

Obrázok 4. Rozšírená pyramída spoločenskej zodpovednosti

Zdroj: HORÁKOVÁ, I., et al.: Strategie firemní komunikace. Praha: Management Press, 2008. 233 s. ISBN 978-80-7261-178-2, s. 93. 
Obrázok popisuje štruktúru rôznych foriem podnikovej angažovanosti a je štandardom, ktorý definuje náklady vynaložené na spoločensky zodpovedné aktivity. Tento štandard známy pod názvom „Štandard zodpovedný podnik“ v roku 2005 zaviedlo české Fórum darcov. [10]

\section{Trojitá výsledovka}

Spoločenská zodpovednost' podniku sa prejavuje integráciou pozitívnych postojov, praktík, či programov do stratégie podniku. Vyžaduje posun pohl'adu na vlastnú spoločenskú rolu z úrovne „profit only“ $\mathrm{k}$ širšiemu pohl'adu v kontexte 3P - ,people, planet, profit“ (l'udia, planéta, prínos) ako znázorňuje obrázok 5.

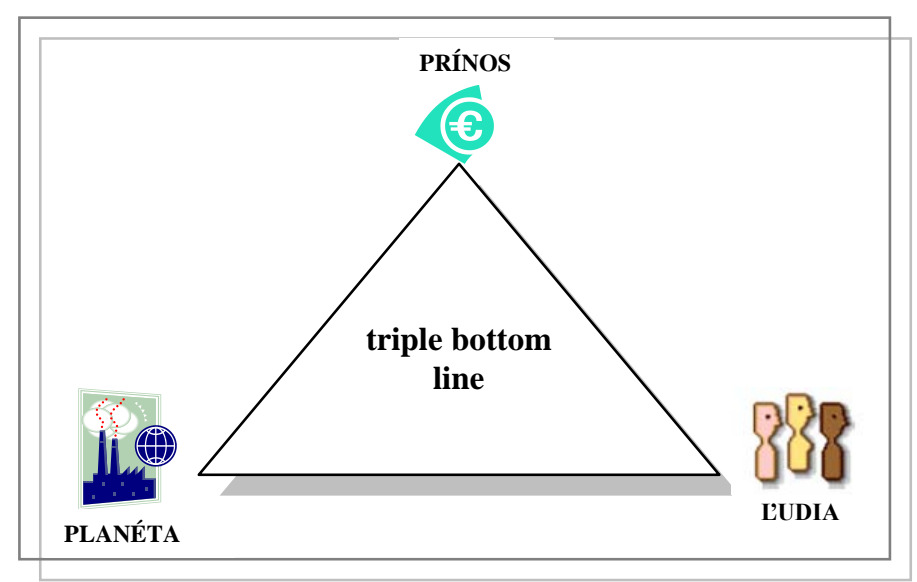

Obrázok 5. Trojitá výsledovka, Zdroj: vlastné spracovanie

Kontext troch prvkov, ktoré tvoria základ pyramídy CSR, znamená fungovanie s ohl'adom na tzv. triple - bottom - line, kedy sa podnik sústred'uje nielen na ekonomický rast, ale aj na environmentálne, či sociálne aspekty svojej činnosti [11]

\section{Porterova konkurenčná výhoda}

Porter definuje, že konkurenčná výhoda je jadrom výkonnosti podniku na tých trhoch, kde je konkurencia. Vzniká z hodnoty, ktorú je podnik schopný vytvorit' pre kupujúcich, a ktorá prevyšuje náklady podniku na jej vytvorenie. [12] Podnik má konkurenčnú výhodu, ak implementuje stratégiu, ktorú konkurenti nie sú schopní napodobnit', prípadne by to pre nich bolo príliš nákladné. Práve takou stratégiou je stratégia zodpovedného podnikania.

\section{Záver}

Kým v minulosti pojem spoločensky zodpovedné podnikanie zosobňovali najmä filantropi, v súčasnosti sa stáva neoddelitel'nou súčast'ou bežnej praxe. Túto skutočnost' výstižne vyjadruje výrok bývalého britského premiéra Gordona Browna: „Spoločenská zodpovednost' podnikov dnes smeruje d'aleko za hranice filantropie minulosti a stáva sa z nej celoročná zodpovednost', ktorú podniky prijímajú s ohl'adom na životné prostredie, ktoré ich obklopuje, na zacielenie do miestnych komunit a s vedomím, že meno značky závisí nielen na kvalite, cene a nezamenitel'nosti, ale rovnako na celkovom spolupôsobení so zamestnancami, s komunitou a životným prostredím.

Požiadavka spoločensky zodpovedného podnikania stojí stále naliehavejšie v popredí všetkých podnikatel'ských aktivít. Vzt'ahuje sa vždy na konkrétne prostredie, jeho charakter a špecifiká. Subjekt tak vždy stojí v prostredí určitých spoločenských hodnôt, preferencií a 
záujmov, ku ktorým sa vzt'ahuje a ktoré ovplyvňujú proces jeho rozhodovania o prevzatí vlastnej zodpovednosti. V súčasnosti sa stále viac presadzuje tendencia chápania zodpovednosti nie ako osobnej zodpovednosti pred určitou konkrétnou situáciou, ale ako zodpovednost' vo vzt'ahu k spoločnosti, l'udstvu a prírode. Preto je teória spoločensky zodpovedného podnikania vysoko aktuálna. Nehovorí sa už ani tak o tom, či sa majú podniky správat' spoločensky zodpovedne, ale skôr o tom, čo to presne znamená a ako túto ideu podporit'. Ťažiskom by mala zostat' prax - realizácia konkrétnych aktivít a opatrení, jasne definované, transparentné a dodržiavané pravidlá, vytváranie a implementácia uznávaných štandardov.

\section{Literatúra}

[1] REMIŠOVÁ, A.: Etika a ekonomika. 2. vyd. Bratislava: Ekonomická univerzita v Bratislave, Vydavatel'stvo Ekonóm, 2004. 238 s. ISBN 80-225-1820-4.

[2] REMIŠOVÁ, A.: Podnikatel'ská etika v praxi. Vydavatel'stvo EPOS, Bratislava. 1999. 272 s. ISBN 80-8057-106-6.

[3] ROLNÝ, I. - LACINA, L.: Globalizace, etika, ekonomika. 3. vyd. Ostrava: Key Publishing, s.r.o., 2008. 281 s. ISBN 978-80-87071-62-5.

[4] BLAŽEK, L. - DOLEŽALOVÁ, K. - KLAPALOVÁ, A.: Společenská odpovědnost' podniku. In: WORKING PAPER č. 9/2005, Centrum výzkumu konkurenční schopnosti české ekonomiky. Brno, 2005. ISSN 1801-4496.

[5] CAROLL, A. B. - BUCHHOLTZ, A. K.: Business and Society - Ethics and Stakeholders Management. 7. vyd. Ohio: SouthWestern Publishing Co., 1999. 970 s. ISBN 978-0-32456939-1.

[6] BUSSARD, A. - BUNČÁK, M. - MARČEK, E. - MAZURKIEWICZ, P. - MARKUŠ, M.: Spoločensky zodpovedné podnikanie. [online]. Bratislava: Nadácia Integra, 2005. [2010-06-06]. Dostupné na: <http://www.nadaciapontis.sk/tmp/asset_cache/link/ 0000013632/Publikacia_SZP.pdf $>$.

[7] FRANC, P. - NEZHYBA, J. - HEYDENREICH, C: Když se bere společenská odpovědnost vážně. 1. vyd. Brno: Ekologický právní servis, 2006. 72 s. ISBN 80-8654408-7.

[8] MAJTÁN, M., et al.: Manažment. Bratislava: SPRINT, 2008. 424 s. ISBN 978-80-8908572-9.

[9] STEINEROVÁ, M. - VÁCLAVIKOVÁ, A. - MERVART, R.: Společenská odpovědnost firem, prưvodce nejen pro malé a střední podniky. Praha: TOP Partners, s.r.o., 2008.

[10]HORÁKOVÁ, I., et al.: Strategie firemní komunikace. Praha: Management Press, 2008. 233 s. ISBN 978-80-7261-178-2.

[11]TRNKOVÁ, J.: Společenská odpovědnost firem - kompletní průvodce tématem \& závěry z průzkumu $v \check{C} R$. Praha: Business Leaders Forum, 2004. $56 \mathrm{~s}$.

[12]ZICH, R.: Strategický rozvoj konkurenčních výhod v koncepci úspěchuschopnosti ve vztahu $k$ pojetí založeném na zdrojích a základních kompetencích. In Ekonomika a management. [online]. Vydanie 3/2009. [Citované 2010-08-01]. Dostupné na: http://www.ekonomikaamanagement.cz/cz/clanek-strategicky-rozvoj-konkurencnichvyhod-v-koncepci-uspechuschopnosti-ve-vztahu-k-pojeti-zalozenem-na-zdrojich-azakladnich-kompetencich.html. ISSN 1802-8934. 